JTE

Journal of Teaching English

Volume 4 No. 3, 2019

e-ISSN: 2548-6810

\title{
PEER FEEDBACK THROUGH FACEBOOK GROUP; Does it bring about effect on students' writing competence at MAN 1 Konawe Selatan?
}

\author{
Aksan Saputra1, Asrun Lio ${ }^{2}$, Muhammad Khusnun Muhsin ${ }^{3}$ \\ kesadauta@gmail.com \\ ${ }^{1}$ Halu Oleo University, Indonesia
}

\begin{tabular}{|c|c|}
\hline ARTICLE INFO & ABSTRACT \\
\hline $\begin{array}{l}\text { Keywords: } \\
\text { Peer Feedback, Facebook } \\
\text { Group, Writing, } \\
\text { Recount Text. } \\
\\
\text { How to cite: }\end{array}$ & $\begin{array}{l}\text { This research is aimed at investigating whether or not } \\
\text { there was a significant effect of Peer Feedback through } \\
\text { Facebook Group on students' writing competence at } \\
\text { MAN } 1 \text { Konawe Selatan in writing recount text. The } \\
\text { design of this research was pre-experimental design } \\
\text { which involved only one class (class X MIA 1) as sample } \\
\text { of this research. The total sample was } 24 \text { students which } \\
\text { selected by using purposive sampling technique. The } \\
\text { instrument of this research was a written test which } \\
\text { focused on three aspects of writing namely organization, } \\
\text { language use and mechanics. The researcher collected the } \\
\text { data by giving pre-test and post-test in order to know } \\
\text { students' writing competence before and after treatment } \\
\text { of Peer Feedback through Facebook Group had been } \\
\text { applying. The researcher used the paired sample t-test in } \\
\text { SPSS } 16 \text { Windows Software to analyze the result of this } \\
\text { research. The finding shows that there is a significant } \\
\text { effect of Peer Feedback through Facebook Group on } \\
\text { students' writing competence. It is proven by the result of } \\
\text { descriptive analysis where the mean score of pre-test was } \\
51.66 \text { and mean score of post-test was } 67.29 \text {. Furthermore, } \\
\text { the result of hypothesis testing showed that the value of } \\
\text { Sig (2-tailed) was } 0.000 \text { which smaller than alpha value } \\
0.05 \text {, means that H0 is rejected and H1 is accepted. } \\
\text { Therefore, it can be concluded that there is a significant } \\
\text { effect of Peer Feedback through Facebook Group on } \\
\text { upgrading students' writing competence in recount text } \\
\text { at MAN } 1 \text { Konawe Selatan. Hence, teaching and learning } \\
\text { writing use Peer Feedback through Facebook Group can } \\
\text { be one of effective methods on upgrading students' } \\
\text { writing competence. }\end{array}$ \\
\hline
\end{tabular}




\section{Introduction}

Teaching writing supposes the essential part of scope of education and becomes a teacher's compound duty in providing the best approaches, techniques and methods during learning process. Since the quality of education relies heavily on the quality of education in school, the learning process becomes a critical step in improving learning outcomes for students. Teachers had been using several accepted strategies and techniques in the teaching and learning process to improve the quality of education, but in reality, Al-Badwawi (2011) stated that teachers are often got some problems in teaching English especially teaching writing skill such as encountered large class in which some of the students are not interested in the learning process and limited time that always faced by teachers that results in teachers' minimum opportunity to give feedback on their students writing work (As cited in Wahyudin, 2018). Therefore, innovative and interesting instructional techniques are needed to provide the students more flexible time and to support them to actively take part in writing process as to enhance their writing ability. Furthermore, giving feedback could be the most powerful impact on learning especially writing competence when feedback is given with effective instruction and given in the right timing. Despite the limited time that faced by teachers as an obstacle to give feedback to their students, peer feedback has been often utilized to support the writing process itself (Rollinson, 2005). Farrah (2012) stated that peer feedback impacts positively on students' self-assessment abilities by giving helpful information to guide revisions and providing opportunities to learn it that improve students' writing skill.

To support the engagement of students in writing, peer feedback process is nowadays often done in online environment since face-to-face peer feedback is considered time-consuming and make students are struggling to expressing and developing their ideas (Choi, 2014). Currently, information and communication technology (ICT) in today's era has been more popular throughout the world since their multi-dimensional uses including in language learning and teaching. As cited 
by Prihatiningsih (2011), she stated that technologies support teaching method by giving learners an interesting environment that encourage students' creativity and provide students' need. Even though the previous studies have concerned the use of Facebook in improving the EFL students' writing competence, there is no further confirmation whether or not online peer feedback with Facebook Group can affect positively on students' writing competence, particularly at the tenth grade students' of MAN 1 Konawe Selatan. Based on the background described above, thus the research question of this research is: Is there any significant effect of peer feedback through Facebook Group on upgrading students' writing competence?

\section{Methods}

In conducting this study, the researcher employed a quantitative research. The researcher used pre experimental design. The purpose of the research is to know whether or not Peer Feedback through Facebook Group can give a significant effect on students' writing competence. The study was conducted on July $24^{\text {th }} 2019$ until August 21 ${ }^{\text {st }}$ 2019. It was done at MAN 1 Konawe Selatan with all students of Class X MIA 1 as samples.

The study used the written test (pre test and post test) as the instrument for the sample to measure their writing competence in writing recount text. The topic of the written test was about My First Day at Senior High School. The data of this study was analyzed quantitatively and was interpreted by using descriptive and inferential statistic. Descriptive statistic was used to know the different results that exist in student pre tests and post tests before and after the treatment. Meanwhile, inferential statistic was used to test the hypothesis by using Paired Sample T-test in SPSS Application version 16.0. It was to know the significance effect of Peer Feedback through Facebook Group in upgrading students' writing competence at MAN 1 Konawe Selatan. 


\section{Findings}

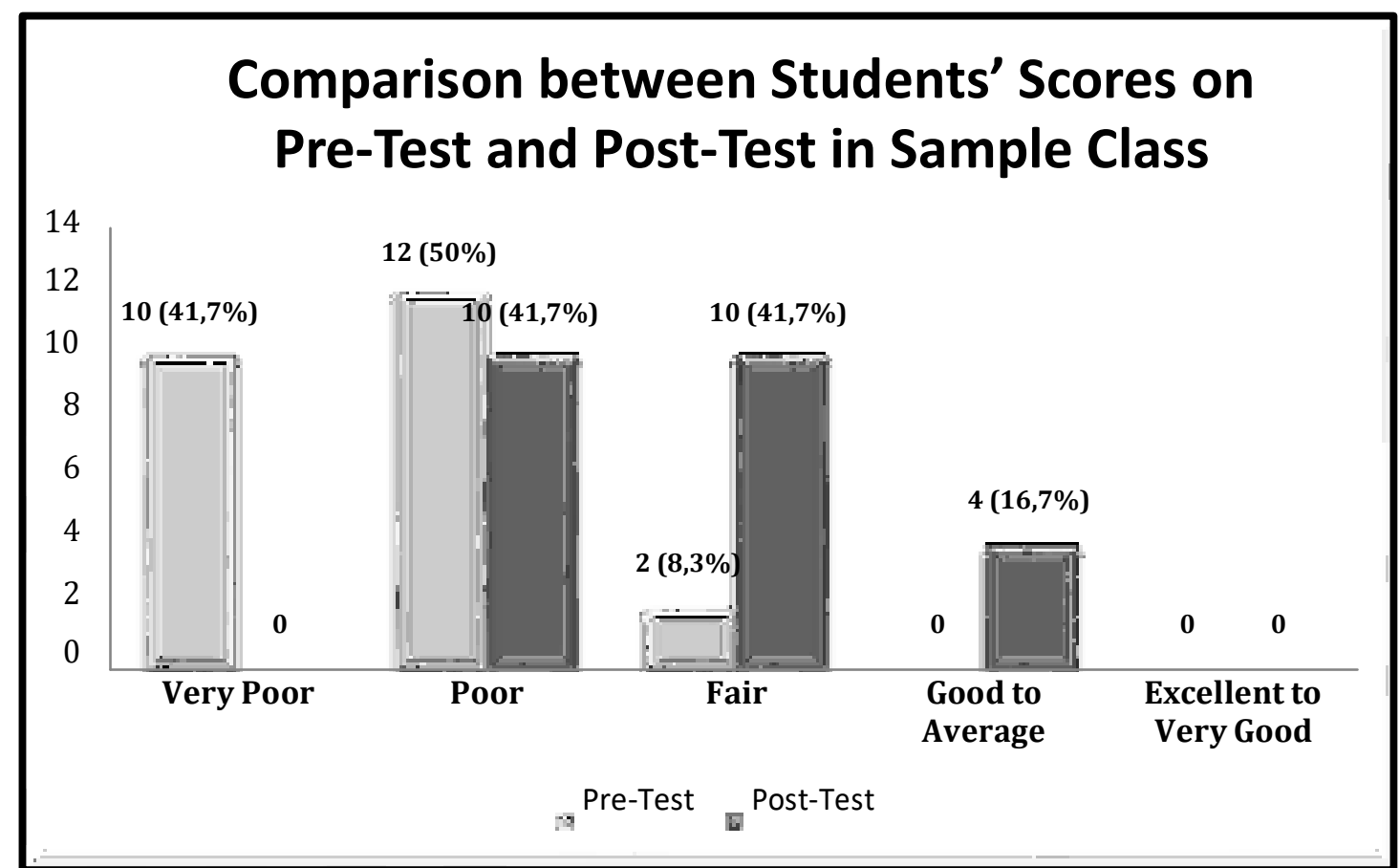

Based on the comparison graph above, it showed that the students who got excellent to very good criteria in post-test and pre-test was 0 students $(0 \%)$, students who got good to average criteria in post-test were 4 students $(16,7 \%)$ while in pretest was 0 students $(0 \%)$, students who got fair criteria in post-test were 10 students $(41,7 \%)$ while in pre-test were 2 students $(8,3 \%)$, students who got poor criteria in post-test were 10 students $(41,7 \%)$ while in pre-test were 12 students $(50 \%)$, and students who got very poor criteria in post-test was 0 students $(0 \%)$ while in pre-test were 10 students $(41,7 \%)$. The findings above showed that there was a significant effect of Peer Feedback through Facebook Group on upgrading students' writing competence at MAN 1 Konawe Selatan. It can be seen from the comparison of students' pre test and post test scores above.

\section{Discussion}

Based on the findings above, it can be concluded that there is a significant improvement on students' writing competence in recount text, and the researcher believed it is because the applying of Peer Feedback through Facebook Group in the 
learning process. It can be seen from the result of the students' score in pre-test and post-test which has been elaborated on findings. The students' mean score before being taught by using Peer Feedback through Facebook Group is 52.95 points, which significantly increased after students had been taught by using Peer Feedback through Facebook Group where they got mean score in 66.62 points. Hereinafter, there are several factors that make the treatment of Peer Feedback through Facebook Group can affectively influent students' writing competence at class X MIA 1 of MAN 1 Konawe Selatan such as the implementation of online-learning environment, the application of collaborative learning technique and the provided peer-feedback guidelines.

The first factor that influenced the effectiveness of the research is the implementation of online-learning environment. Online-learning environment is a new electronic-learning opportunity where could be done in post face-to-face conventional class in order to make students to be able to create, to improve imaginative attitude, creating an independent self-exploration and to easily adapt with new development in their environment. According to Black (2005), online discussions have the possibility to motivate student examination and create a context in which collaborative learning occurs, promoting both reflection and critical thinking. A kind of online-learning environments implemented in this research is Social Networking Sites (SNS) which in this case is Facebook Group. The used of Facebook Group as a platform for implementing online-learning environment in school offers several benefits such as the attractive facilities that can be used by either students or teacher, the familiar interface that is not make confused to be used, and the ease of access because Facebook site can be accessed freely without internet quota. Since Facebook becomes the most popular social networking website and the most widely used social media especially for Indonesian students, the researcher got positive responses from students when the researcher told that Facebook would be used as a media in online-learning process. The reason of why students were very excited to learn writing with using Facebook was because Facebook is their most frequently used social media and they were curious on how they could learn writing 
and build interaction through online-learning environment. Hence, the implementation of online-learning environment in this research was the one of factors that gave significant improvement on students writing competence because it provides a number of benefits such as the new learning opportunities for both students and teacher, humanizing the environment and build community through online interaction.

The second factor is the application of collaborative learning. The collaborative learning approach is a learning approach that builds a social interaction which can give influence in learning acquisition. Vygotsky (1978), stated that collaborative learning including Online Peer Feedback can give influence in learning acquisition because students are easier to compose their knowledge by interact or giving feedback to one another. Similar to enhancing writing skills, students will find it easier to understand how to write a good text by using a good grammar, logical organization and so on by doing it together with their relatives. The implementation of collaborative learning in this research was done by pairing students and asking them to work together for giving and taking feedback in pair. According to Cahyono (2016), peer feedback can be applied by pairing or grouping students, it depends on teacher's need and the total number of the sample. The researcher deliberated previously to apply both grouping and pairing, and considered to not grouping them because the researcher thought the students would get many feedbacks that could be different from one another and could be overlapping. The researcher found that by pairing students in case to implementing the peer feedback could make them be more focus on correcting their peer's writing. Moreover, students' cooperation in giving and taking feedback has improve because they were paired in three different pairs to work together in three meetings that made them could give a feedback to various students and take a feedback for diverse sources of students. In short, the applying of collaborative learning in this case is by pairing them was one of the factors that affecting the improvement of students' writing competence. 
The last factor is the provided peer-feedback guideline. Corgan (2004), the use of peer feedback in online learning environment gives a number of benefits such as increasing the timeliness of feedback, humanizing the environment, offering new learning opportunities for both givers and recipients of feedback, and building community through online interaction. In an online interaction, all students can participate in one another's learning by providing constructive feedback to their peers. Through this process, they also achieve greater understanding and appreciation for the perspective of their peers. Peer Feedback on Facebook Group was implemented in post-face-to-face meeting after it got introduced to students and taught how to give feedback based on the provided guidelines in classroom meeting. It took a lot of efforts and much time to explain how to give feedback in pair by following the provided guidelines because the researcher expected to establish that all students give feedback as the provided guidelines directly. The explanation of three components of writing assessment also took specific time to be explained because the students' understanding of the components was important in directing them to give feedback to their pair writing draft.

Based on the elaboration above, it can be said that there was improvement on students' writing competence which can be seen on the composition of pre-test score and post-test score. Furthermore, Peer Feedback through Facebook Group can improve students' writing competence at first year students of MAN 1 Konawe Selatan.

\section{Conclusion and Recommendation}

Based on the findings and discussion, the researcher concludes that there is a significant effect of applying Peer Feedback through Facebook Group on students' writing competence at the first year students of MAN 1 Konawe Selatan. Peer Feedback on Facebook Group is a strategy in language learning that promotes students to participate actively in learning especially in English course. It provides the opportunity for the students to encourage them to be more active in learning 
because it is an online-based learning, which gives them opportunity to discover their ideas and allows them to choose their own words. The improvement of students' writing competence had significantly affected by several factors such as the implementation of online-learning environment, the applying of collaborative learning technique and the provided peer-feedback guidelines. It can be seen from the improvement of students' mean scores from pre-test to post-test. In post-test, students' mean score is higher than in pre-test. They also have increased in three aspects of writing such as language use, organization and mechanics. In addition, the improvement also was seen on aspects of students' motivation and students' critical thinking.

The finding of the research showed that there is an effect of Peer Feedback trough Facebook Group on students' writing competence. Therefore, the researcher tries to give some suggestion as follows: For students; in the online learning process, students have to be more active. They do not need to feel shy or afraid of making mistakes in giving feedback to their peer because the teacher will help them to correct the mistakes made in classroom meeting. For teachers; teachers need to use Information and Communication Technology (ICT) in this case is Social Media such as Facebook and apply peer feedback on it to support their teaching process because it gives opportunities to develop various activities and a flexibility of time. For the further researcher; after conducting this research, the researcher recommends that for the further researcher who wants to do the same study to maximize peer feedback process which the receiver of feedback should be given an opportunity to response the feedback that has given by their pairs, to use different kind of social media and do further research about students' motivation and critical thinking which used Peer Feedback on Facebook Group.

\section{References}

Al-Badwawi, H. S. (2011). The Perceptions and Practices of First Year Students' Academic Writing at the Colleges of Applied Sciences in Oman. Oman: University of Leeds (Doctoral Dissertation).

Black, A. (2005). The Use of Asynchronous Discussion: Creating a Text of Talk. Contemporary Issues in Technology and Teacher Education, 5 (1). Retrieved October 


\section{Journal of Teaching English Vol. 4 No. 3, 2019}

3, 2005 from http://www.citejournal.org/vol5/iss1/languagearts/article1.cfm .

Cahyono B. Y., Amrina R. (2016). Peer Feedback, Self Correction and Writing Proficiency of Indonesian EFL Students. Arab World English Journal, 178-193.

Choi, J. (2014). Online Peer Discourse in a Writing Classroom. International Journal of Teaching and Learning in Higher Education, Vol. 26 (2) , 217-231.

Corgan, R. H. (2004). Making Your Online Course Successful. Business Education Forum $58(3), 51-53$.

Farrah, M. (2012). The Impact of Peer Feedback on Improving the Writing Skills among Hebron University Students. An-Najah University Journal Res. , Vol. 26(1).

Rollinson, P. (2005). Using Peer Feedback in the ESL Writing Class. ELT Journal, 59(1), 23-30.

Vygotsky, L. S. (2000). Mind in Society: The Development of Higher Psychological Processes. Cambridge, MA: Harvard University Press. 